Article

\title{
Renewable Energy Technology Selection Problem Using Integrated H-SWARA-MULTIMOORA Approach
}

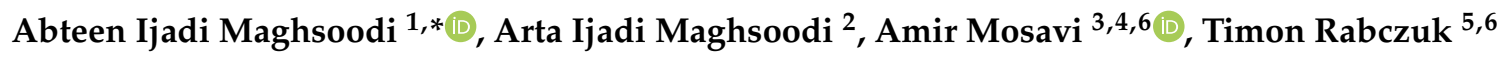 \\ and Edmundas Kazimieras Zavadskas ${ }^{7}$ (i) \\ 1 Department of Industrial Engineering, Science and Research Branch, Islamic Azad University, \\ Tehran 1477893855, Iran \\ 2 Department of Chemical and Petroleum Engineering, Science and Research Branch, Islamic Azad University, \\ Tehran 1477893855, Iran; arta.ijadimaghsoodi@srbiau.ac.ir \\ 3 Institute of Automation, Kando Kalman Faculty of Electrical Engineering, Obuda University, \\ 1034 Budapest, Hungary; amir.mosavi@kvk.uni-obuda.hu \\ 4 Institute of Advanced Studies Koszeg, iASK, 9730 Koszeg, Hungary \\ 5 Department of Computer Engineering, College of Computer and Information Sciences, King Saud \\ University, Riyadh 11362, Saudi Arabia \\ 6 Institute of Structural Mechanics, Bauhaus Universität-Weimar, D-99423 Weimar, Germany; \\ timon.rabczuk@uni-weimar.de \\ 7 Institute of Sustainable Construction, Vilnius Gediminas Technical University, LT-10223 Vilnius, Lithuania; \\ edmundas.zavadskas@vgtu.lt \\ * Correspondence: aimaghsoodi@srbiau.ac.ir; Tel.: +98-912-643-3448
}

Received: 28 October 2018; Accepted: 25 November 2018; Published: 28 November 2018

check for updates

\begin{abstract}
Due to the adaptation of recent pollution mitigation and justification policies there has been a growing trend for electricity generation from various renewable resources. The selection of the optimal renewable energy technology could be measured as a complex problem due to the complication of forthcoming circumstances in any country. Consequently, the proposed similar complex assessment problem can be tackled with the support of Multiple Attribute Decision Making (MADM) methods. The current research study investigates a technology selection problem by proposing a hybrid MADM approach based on the Step-Wise Weight Assessment Ratio Analysis (SWARA) approach with a hierarchical arrangement combined with the Multi-Objective Optimization on the basis of Ratio Analysis plus the full MULTIplicative form (MULTIMOORA). Ultimately, a conceptual case study regarding the selection of the optimal renewable energy technology based on a conceptual development project in Iran has been examined by the proposed combinative MADM methodology.
\end{abstract}

Keywords: renewable energy; technology selection problem; sustainable energy evaluation; sustainable energy developments; sustainable developments; hierarchical SWARA; MULTIMOORA; multiple criteria decision making (MCDM); Multiple Attribute Decision Making (MADM); ranking

\section{Introduction}

In a century that technological advancements and continuous developments are at the cutting edge, it is unreasonable to only be dependent on unsecure and limited sources such as fossil fuels. It is clear that this dependence is not a secure preference due to the energy demand and population growth all around the world. Renewable energy sources count as a key alternative to fossil fuels, which plays a crucial part in supplementing energy via clean alternative energy sources. In the past few years, 
many research studies have found that these environmentally friendly energy sources are capable of replacing limited and conservative energy sources [1]. There are quite a few renewable energy technologies that have been developed vastly in past few years such as wind energy, hydropower, solar radiation, and geothermal energy. One of the most challenging practical issues in order to use renewable energy sources is to select which technology will provide the optimal solution based on various factors and attributes. This means while multiple renewable energy technologies are available, there are also various socio-economic criteria that have to be considered. Hence, this problem counts as a decision-making problem.

It is just a fact that almost every time there is a similar complex problem regarding the selection and assessment of the best alternative, one of the optimal ways to resolve it is multiple attribute decision-making (MADM) approaches. Therefore, in the case of the current study, due to the availability of multi-dimensional criteria along with multiple alternatives, the decision-making process can be measured as an MADM problem [2]. In the past few years, many energy planning systems have utilized MADM approaches to obtain elevated productivity and efficiency in development and execution of renewable energy technologies [1,3-5]. The main reason for attracting substantial attention to this approach is because these methods can be aimed at complex problems that are considered a mixture of multiple criteria. Moreover, despite the fact that there are few papers available in the literature of energy planning systems, none of the previous studies tackled a renewable technology selection problem in Iran. This is unexpected, because Iran is a country of four seasons, which has a huge potential to grow in green and sustainable developments in regards to renewable energy technologies.

The primary motivation of the current study is to tackle a renewable energy technology selection problem presenting a hybrid MADM approach including a Multi-Objective Optimization on the basis of Ratio Analysis plus the full MULTIplicative form (MULTIMOORA) method combined with a hierarchical Step-Wise Weight Assessment Ratio Analysis (SWARA) approach. In this regard, the present study considered multiple criteria along with multiple renewable energy technologies as alternatives to form the main decision matrix. Various quantitative and qualitative criteria were identified and evaluated in order to find and select the optimal renewable energy source. The mentioned criteria were defined based on their associated sub-criteria obtained from literature review and expert comments. Moreover, the experts were requested to evaluate the criteria and sub-criteria in view of their significance in renewable energy technologies. Eventually, the hierarchical SWARA method was combined with the MULTIMOORA approach to assess and evaluate the renewable energy technologies.

The remainder of the current study is organized as follows. Section 2 provide a comprehensive literature overview of the applications and developments of the MCDM approaches in renewable energy technology selection along with reviews on the MULTIMOORA and SWARA methods. In Section 3, the hybrid MADM approach incorporating the H-SWARA method along with the MULTIMOORA technique is provided to clarify the research methodology of the present study. Moreover, Section 4 presents the applications of the suggested approach in a real-world case study for a renewable energy technology selection problem directed by a cross-industrial multi-national company in Iran based on a conceptual development program, whereas Section 5 offers a conclusion of the current research study along with guidelines for forthcoming and future studies.

\section{Literature Review}

\subsection{Survey on Applications of MCDM Methods in Renewable Energy Technology Selection}

The necessity of using renewable energies has been discussed all over the world for many years. It is a clear fact that the evaluation process of the renewable energy technology projects counts as a multi-attribute decision making (MADM) problem. In the past few years, many research studies have tackled the renewable energy technology selection problem with various MADM methods. 
Kaya and Kahraman [6] applied a hybrid MADM approach based on integrated fuzzy VlseKriterijumska Optimizacija I Kompromisno Resenje (VIKOR) and analytic hierarchy process (AHP) methodology in a renewable energy development planning problem in Turkey. Yazdani-Chamzini et al. [1] suggested an application of the COPRAS (COmplex PRoportional ASsessment) method combined with an Analytic Hierarchy Process (AHP) approach to tackle a problem in regard to the best renewable energy project for the Spanish Government. Ahmad and Tahar [7] presented an application of AHP in an assessment of renewable energy sources aimed at sustainable expansion of electricity generation systems in Malaysia.

Şengül et al. [8] presented an application of the fuzzy TOPSIS (techniques for order performance by similarity to ideal solution) method consolidated with the interval Shannon's entropy to evaluate renewable energy sources in Turkey. Ignatius et al. [9] suggested multiple renewable energy planning schemes utilizing a hybrid method utilizing fuzzy VIKOR and AHP approaches selecting the optimal and suitable renewable energy option in Istanbul. Büyüközkan and Güleryüz [10] proposed a hybrid MCDM methodology based on the combination of Decision Making Trial and Evaluation Laboratory Model (DEMATEL) technique with Analytic Network Process (ANP) for renewable energy resources selection in Turkey. Kumar et al. [11] presented a comprehensive review of MCDM methods applied in sustainable renewable energy developments. Haddad et al. [12] suggested a hybrid approach combining the AHP method and experts' feedback to evaluate various renewable energy preferences for the Algerian electricity system. Büyüközkan and Güleryüz [13] proposed a hybrid method integrating linguistic interval fuzzy sets with DEMATEL, ANP, TOPSIS techniques to present an assessment of renewable energy resources in Turkey.

Çolak and Kaya [4] presented an application of the hybrid AHP method established on interval type-2 fuzzy sets and hesitant fuzzy TOPSIS approach to prioritize the renewable energy options in Turkey. van de Kaa et al. [14] suggested an application of the best-worst method (BWM) in a selection process in regard to biomass thermochemical conversion technology in the Netherlands. Yazdani et al. [2] applied a combinative MADM method utilizing DEMATEL-ANP approach for the evaluation and selection of renewable electricity generation technologies in the EU. Büyüközkan et al. [5] proposed a novel renewable energy selection model for United Nations' sustainable development goals based on a combination of AHP method with COPRAS technique using hesitant fuzzy linguistic (HFL) term set arrangements. Wu et al. [15] suggested an assessment of the renewable power sources utilizing a fuzzy MCDM based on cumulative prospect theory in China. Karunathilake et al. [16] proposed an application of a fuzzy MCDM methodology under uncertainty in renewable energy selection for net-zero energy communities.

\subsection{Survey on Applications and Developments of the MULTIMOORA Method}

One of the most effective and straightforward MADM methods that have been suggested in recent years is the multi-objective optimization on the basis of ratio analysis (MOORA) plus the full multiplicative form (MULTIMOORA) which were established by Brauers and Zavadskas [17]. The MULTIMOORA method incorporates three subordinate ranks including the ratio system (RS), the reference point (RP), and the full multiplicative form (FMF), by utilizing the theory of dominance to obtain the ultimate rank of the method. There have been many applications and developments of the MULTIMOORA method in recent years in various fields [18-23].

Few examples of developments and propositions of the mentioned approach are demonstrated in this section. Hafezalkotob et al. [24] recommended an extension of the MULTIMOORA approach with interval-valued numbers to tackle a material selection problem regarding the optimal material for power gears. Deliktas and Ustun [25] applied a combination of the fuzzy MULTIMOORA and multi-choice conic goal programming in a student assessment problem. Ijadi Maghsoodi et al. [26] proposed an application of the MULTIMOORA method integrated Shannon's entropy in a similar complex selection problem considering the optimal organizational performance appraisal method in Iran. Brauers et al. [27] applied the MULTIMOORA approach in a comparison of the effectiveness factor 
of the firms offering facilities management along with a comprehensive facilities management sector analysis and future forecast in Lithuania. Wu et al. [28] proposed an extension of the MULTIMOORA approach by combining the technique with the probabilistic linguistic distance measures and the Borda rule applied in a selection problem consisting of the joint karaoke television brands.

Ijadi Maghsoodi et al. [29] suggested a novel and hybrid framework based on cluster analysis and the MULTIMOORA approach in a big data supplier selection problem in an information and communications technology (ICT) organization in Iran. Peng and Wang [30] suggested a group MCDM method based on the MULTIMOORA approach combined with the normal cloud model and Z-numbers. Hafezalkotob et al. [31] presented a combinative decision support system consolidating target-based WASPAS and MULTIMOORA methods with the BWM in an olive harvester machine selection problem. Tian et al. [32] suggested an improved version of the MULTIMOORA technique in regard to interdependent inputs of simplified neutrosophic linguistic term sets and information. Eghbali-Zarch et al. [33] presented an application of the SWARA consolidated with MULTIMOORA method in a fuzzy environment in a medication selection problem and pharmacological therapy selection for Type 2 Diabetes (T2D).

\subsection{Survey on Applications and Developments of the SWARA Method}

The Step-Wise Weight Assessment Ratio Analysis (SWARA) method is a newly-proposed method which is applied in order to weight the criteria suggested by Kersuliene et al. [34]. The proposed method is applied on experts' knowledge, information, and experiences of the criteria in order to calculate the significance of coefficients. Few examples of propositions and applications of the SWARA method in various fields are demonstrated in the current section.

Hashemkhani Zolfani et al. [35] proposed a hybrid method combining the SWARA and Weighted Aggregated Sum-Product Assessment (WASPAS) approaches which have been applied on a selection of a suitable locations for a new shopping mall in Tehran, Iran. Keršulienè and Turskis [36] suggested a hybrid method based on additive ratio assessment (ARAS) method using the principles of fusion of fuzzy information combined with the SWARA approach which applied to an architect selection problem. Hashemkhani Zolfani et al. [37] recommended a hybrid methodology based on the SWARA and VIKOR methods used in a problem considering the selection of the optimal mechanical longitudinal ventilation of tunnel pollutants during automobile accidents. Similarly, Hashemkhani Zolfani et al. [38] investigated the success factors of online games based on explorer with the SWARA method. Hashemkhani Zolfani et al. [39] suggested an application of the SWARA method combined with Yin-Yang balance (YYB) theory in producing and designing products with new perspectives consisting of both international and local views. Hashemkhani Zolfani and Bahrami [40] had investigated high tech industries in Iran to prioritize them based on investments consisting of the SWARA-COPRAS approach. Vafaeipour et al. [41] applied the SWARA-WASPAS technique in an assessment of 25 scattered cities all around regions of Iran to prioritize the implementation of solar projects.

Karabasevic et al. [42] offered a combination of the SWARA-ARAS method in order to present an assessment of companies according to the indicators of corporate social responsibility. Hashemkhani Zolfani et al. [43] applied the SWARA-COPRAS method in an assessment considering construction projects of hotels based on environmental sustainability. Hashemkhani Zolfani et al. [44] suggested an application of the SWARA method in a project selection consisting of technology foresight about research and development projects. Yazdani et al. [45] applied a combination of SWARA, WASPAS methods with the quality function deployment (QFD) framework in a green supplier selection problem. Nakhaei et al. [46] presented an application of the Simple Multi-Attribute Ranking Technique (SMART) combined with SWARA method for rapid evaluation of the vulnerability of office buildings to blast in the Swiss Re Tower. Karabasevic et al. [47] proposed an application of the SWARA-ARAS approach in a personnel selection problem. Nakhaei et al. [48] suggested the SWARA-COPRAS method in an evaluation of light supply in the public underground safe spaces. Tayyar and Durmuş [49] compared three type of weighting method including Max100, SWARA and Pairwise Weight Elicitation 
Methods (WEM) in MCDM problems to select the optimal car to buy. Mavi et al. [50] applied a hybrid SWARA-MOORA technique based on fuzzy set input data in order to select the optimal sustainable third-party reverse logistics provider in the plastic industry. Dahooie et al. [51] applied a novel approach considering SWARA-ARAS method using interval-valued fuzzy sets for evaluation of oil and gas well drilling projects. Dahooie et al. [52] applied the SWARA-ARAS-G approach in a competency-based IT personnel selection problem.

\subsection{Research Gaps and Contributions of the Current Study}

While there were a number of research studies in the field of renewable energy technology selection in recent years, there are only a few studies that have covered the applications of MADM approaches in this area of research. In this regard, in the current study, a hybrid proposition was made based on an MADM approach to aid the evaluation of the renewable energy selection problem. To the best of authors' knowledge, not a single study proposed and developed an application of the hybrid integrated H-SWARA-MULTIMOORA approach in a renewable energy technology selection. Moreover, in this study, a hierarchical structure of the SWARA weighting technique was demonstrated, that is an innovative approach to consider criteria along with their related attributes as sub-criteria in a similar complex problem in regard to a renewable energy technology selection problem.

Moreover, there is not a single study that analyzed renewable energy technology selection in Iran. Although there have been many studies that analyzed different aspects of renewable energy sources in Iran, none of the research studies have investigated multiple choices of renewable energies for the recent development programs in Iran. Based on expert comments, in more than $80 \%$ of the renewable energy development programs, the final decision of the final renewable source selection has been imposed by governments and policymakers without paying enough attention to the aspects of associated circumstances of multiple renewable energy sources. The reason for this problem is that still, in many third world countries, sustainability of renewable energies counts as a vanity project for governments. In this study, a conceptual renewable energy technology selection was analyzed in order to elucidate the best renewable energy source in a specific area supported by a multi-cultural cross-industrial organization targeting green developments in Iran. After identifying multiple criteria from the literature of renewable energy technologies, various attributes and their related criteria were selected by experts, along with multiple options as alternatives of the renewable energy sources. Furthermore, in this study, an integrated MADM method based on the H-SWARA-MULTIMOORA approach was applied in order to consider the hierarchical structure of the criteria along with giving an optimal solution to the renewable energy selection problem in the suggested case-study. Therefore, the novelties of the current study are both in practical and theoretical aspects. To summarize, the aims of the current study is twofold. First, the problem modeling of a conceptual renewable energy technology selection based on a conceptual development program in a specific part of Iran with a hybrid novel MADM method. Second, the development of a hybrid MADM method based on a hierarchical structure with a combination of the SWARA and MULTIMOORA methods.

\section{Materials and Methods}

\subsection{Hierarchical Step-Wise Weight Assessment Ratio Analysis (H-SWARA)}

As overviewed in Section 2.3. Kersuliene et al. [34] suggested the SWARA method in order to achieve the weights of the criteria in an MADM problem. The SWARA technique is recognized as an expert-oriented method where all of the analyzed criteria are ranked from the first to the last one based on experts' explanations. The SWARA method assigns the weight of the most significant criterion as the first ranked objects, and evidently, the lowest precedence is set to the least significant criterion. Accordingly, based on the average value of ranks, overall ranks are computed. Due to the straightforwardness of the SWARA method, the decision-makers can easily conduct a teamwork. Accordingly, based on the average value of ranks, overall ranks are achieved. The foundation and 
initial procedure for the determination of the criteria weights employing SWARA method can be initiated by arranging each and every criterion based on expert interpretations and remarks [1]. Then, after the primary assortment, the comparative significance of the average value $s_{j}$ should be obtained from the second criterion.

Computation of this value is based on a simple procedure; the relative importance of the criterion $j$ in relation to the previous criterion $j-1$, employing a number between 1 and 9 . The next step is to calculate the coefficient $k_{j}$ as determined in Equation (1) [34]:

$$
k_{j}=\left\{\begin{array}{ll}
1 & j=1 \\
s_{j}+1 & j>1
\end{array},\right.
$$

Consequently, the computation of the recalculated weight $w_{j}$ can be obtained as demonstrated in Equation (2) [35]:

$$
w_{j}=\left\{\begin{array}{ll}
1 & j=1 \\
\frac{x_{j}-1}{k_{j}} & j>1
\end{array}, .\right.
$$

The final step in the calculation of the criteria weights is to obtain the results of the Equation (3) as the final weight of the criteria calculated from the SWARA approach. In which, $q_{j}$ signifies the relative weight of the criterion $j[34,35]$.

$$
q_{j}=\frac{w_{j}}{\sum_{k=1}^{n} w_{j}} .
$$

To include sub-criteria evaluations of the SWARA approach, a hierarchical form influenced by the AHP method has been consolidated with the suggested technique. The AHP method apprehensions a hierarchical structure based on the pairwise comparison [53,54]. Accordingly, in order to apply the mentioned hierarchical form to the SWARA technique, weights of criteria and sub-criteria need to be obtained to calculate the final weights of decision-making attributes. In order to present a clarification on the hierarchical structure of the SWARA method, Figure 1 illustrates the hierarchical structure of the proposed renewable energy technology selection problem based on the conceptual development of the current research study. Eventually, in Section 4, the mathematical calculation of the process is demonstrated extensively based on a real-world case-study.

\subsection{Multi-Objective Optimization on the Basis of Ratio Analysis Plus the Full Multiplicative Form (MULTIMOORA)}

Brauers and Zavadskas [17] extended the multi-objective optimization by ratio analysis (MOORA) adding the full multiplicative form to the MOORA method which resulted in the MULTIMOORA method. This robust technique is established based on three parts including the ratio system, the reference point, and the full multiplicative form [27]. Similar to any other MADM approach, the first stage of the MULTIMOORA technique is to form the decision matrix $X$ based on the performance index $x_{i j}$ of $i$ th alternative respecting $j$ th attribute $i=1,2, \ldots m$ and $j=1,2, \ldots n$ [29]. It is also worth mentioning that $w_{j}$ signifies the significance coefficients of $j$ th attribute $j=1,2, \ldots n$. In this study the significance coefficients or weights of criteria have been obtained from the SWARA method.

$$
\begin{gathered}
X=\left[x_{i j}\right]_{m \times n^{\prime}} \\
w_{j}^{s}=\left[w_{j}\right]_{n^{\prime}} w_{j}^{s}=\left[w_{j}\right]_{n} .
\end{gathered}
$$

Moreover, to make performance indices related to each alternative and criterion comparable in the MULTIMOORA method, the decision matrix parameters should be dimensionless. The primary reason that the decision matrix should be dimensionless is that different criteria have different measurement 
scales, for example cost and time might be two criteria in a similar complex problem. In order to consider both in the computation procedure these attributes should be normalized [26].

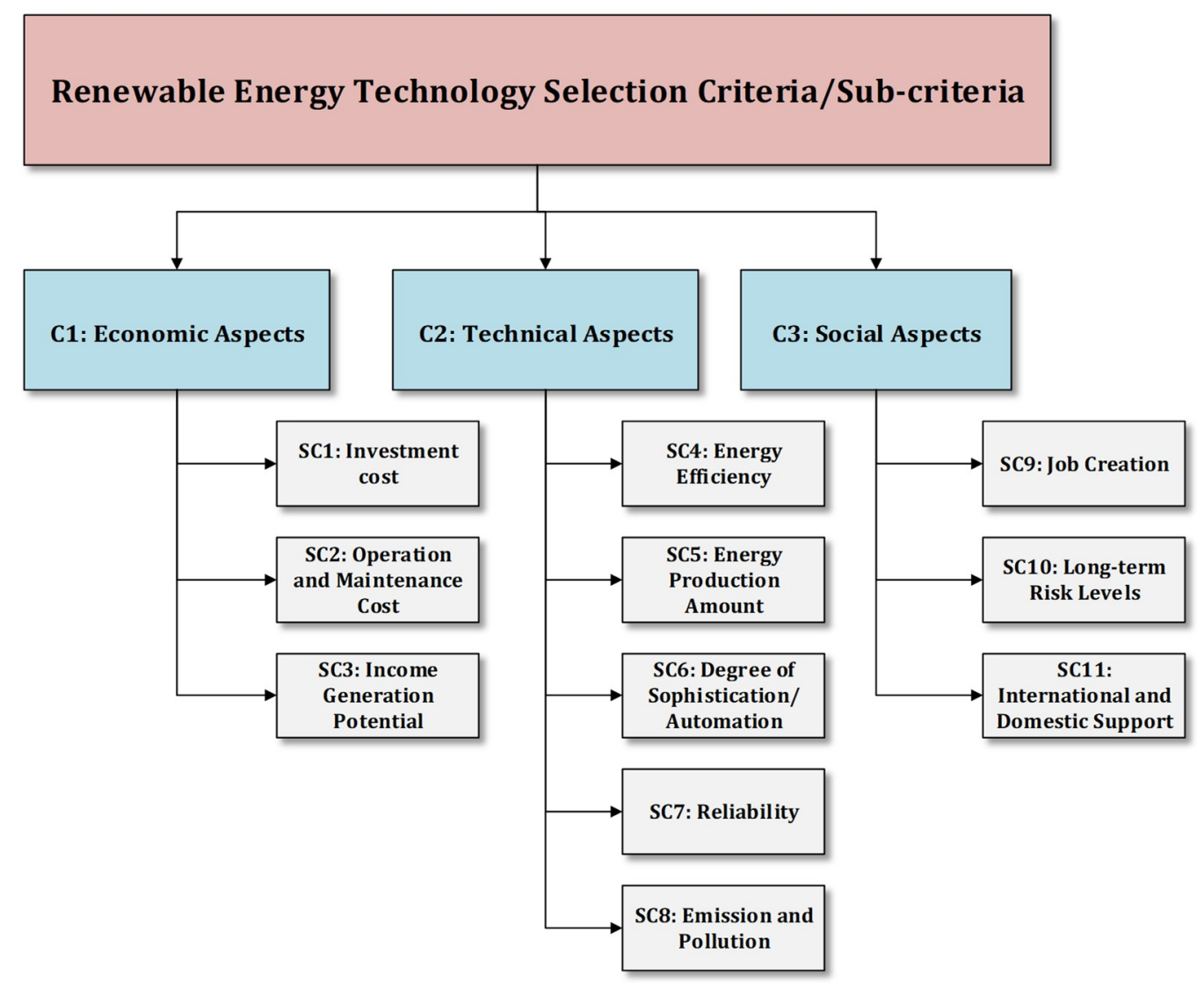

Figure 1. The hierarchical structure of the proposed renewable energy technology selection problem criteria and sub-criteria.

For that reason, the decision matrix is a normalization ratio of comparison amongst individual responses of each alternative associated with each criterion as a numerator, and a denominator that is a demonstrative for all alternative performances on that criterion [26]. The dimension dominator is computed based on the square root of the sum of squares of performance indices per attribute, as presented in Equation (6) [29]. In which, $X_{i j}^{*}$ signifies the normalized performance index of $i$ th alternative regarding $j$ th attribute $i=1,2, \ldots m$ and $j=1,2, \ldots n$ and $x_{i j}$ displays the performance index of $i$ th alternative with respect to $j$ th attribute $i=1,2, \ldots m$ and $j=1,2, \ldots n$ [17].

$$
X_{i j}^{*}=\frac{x_{i j}}{\sqrt[2]{\sum_{i=1}^{m} x_{i j}^{2}}} .
$$

\subsubsection{The Ratio System Approach}

The foundations of the ratio system are based on the normalization of the decision matrix utilizing Equation (6), in which the normalized performance indices are added for beneficial attributes or subtracted for non-beneficial attributes which means that these responses are added in case of maximization and subtracted in case of minimization.

The total assessment values $y_{i}^{*}$ of alternative $j$ along with the weights of criteria calculated from the SWARA method $w_{j}$ can be positive or negative based on the totals of calculations using Equation (7) [26]. In which, $g$ specifies the objectives in order to be maximized and $(n-g)$ designates the objectives being minimized. Consequently, the optimal alternative of the ratio system $A_{R S}^{*}$ is an 
ordinal ranking of its associated assessment value $y_{i}^{*}$ which has the highest total calculated based on Equation (8) [17].

$$
\begin{gathered}
y_{i}^{*}=\sum_{j=1}^{g} w_{j} X_{i j}^{*}-\sum_{j=g+1}^{n} w_{j} X_{i j}^{*}, \\
A_{R S}^{*}=\left\{A_{i} \mid \max _{i} y_{i}^{*}\right\} .
\end{gathered}
$$

\subsubsection{The Reference Point Approach}

Similar to the ratio system, the second stage of the MULTIMOORA method starts based on the normalization calculations of Equation (6). A maximal objective reference point is also determined in the technique which is acquired by Equation (9) [27]. In which, $r_{j}$ symbolises the $i$ th co-ordinate of the maximal objective reference point vector [24].

$$
r_{j}=\left\{\begin{array}{ll}
\max _{i} X_{i j}^{*} & \text { in case of maximization } \\
\min _{i} X_{i j}^{*} & \text { in case of minimization }
\end{array} .\right.
$$

Subsequently, the maximum value of the deviation of a performance index from the reference point $r_{j}$ which could be obtained as $\left(r_{j}-X_{i j}^{*}\right)$ for each alternative $z_{i}^{*}$ respecting weights of all criteria calculated from the SWARA method $w_{j}$ can be calculated as Equation (10) [24]. Eventually, computation of the ideal alternative $A_{R P}^{*}$ is obtained by calculating the minimum value of the assessment value $z_{i}^{*}$ obtained from Equation (11) [55].

$$
\begin{gathered}
z_{i}^{*}=\max _{j}\left|\left(w_{j} r_{j}-w_{j} X_{i j}^{*}\right)\right|, \\
A_{R P}^{*}=\left\{A_{i} \mid \min _{i} z_{i}^{*}\right\} .
\end{gathered}
$$

\subsubsection{The Full Multiplicative Form}

The third phase of the MULTIMOORA method has been developed based on a concept in economic mathematics by Brauers and Zavadskas entitled the full multiplicative form [55].

Equation (12) provides the calculation of the full multiplicative form, in which $g$ denotes as the objectives to be maximized and $(n-g)$ specifies as the objectives to be minimized [55]. The numerator of Equation (12) indicates the product of performance indices of $i$ th alternative relating to beneficial attributes. The denominator of Equation (12) i.e., $U_{i}^{\prime}$ characterizes the product of performance indices of $i$ th alternative relating to non-beneficial criteria respecting weights of each criterion obtained from the SWARA approach $w_{j}$.

Moreover, by using normalized measurements of the decision matrix which have obtained from Equation (6), similar equation to $U_{i}^{\prime}$ can be established as Equation (13). It is worth mentioning that, in order to preserve a harmony among all parts of calculations in the current study the normalized form of the full multiplicative form has been used in order to calculate the assessment values of the full multiplicative form $U_{i}^{*}$.

$$
\begin{aligned}
U_{i}^{\prime} & =\frac{\prod_{j=1}^{g}\left(x_{i j}\right)^{w_{j}}}{\prod_{j=g+1}^{n}\left(x_{i j}\right)^{w_{j}}}, \\
U_{i}^{*} & =\frac{\prod_{j=1}^{g}\left(X_{i j}^{*}\right)^{w_{j}}}{\prod_{j=g+1}^{n}\left(X_{i j}^{*}\right)^{w_{j}}} .
\end{aligned}
$$

Consequently, the ideal alternative $A_{M F}^{*}$ is achieved regarding the maximum assessment value $A_{i}$ between all assessment values of $U_{i}^{*}$ presented in Equation (14) [26].

$$
A_{M F}^{*}=\left\{A_{i} \mid \max _{i} U_{i}^{*}\right\}
$$




\subsubsection{The Dominance Theory}

The final stage of the MULTIMOORA method is the utilization of the dominance theory for integrating and ranking subordinate alternatives [26,56-59]. In this method after calculating of the subordinate ranks, they can be integrated into a final ranking, which is the final step of the MULTIMOORA method. In dominance theory, a summary of the arrangement of the three MULTIMOORA methods is made based on cardinal and ordinal scales [57]. For a more detailed explanation of the dominance theory, readers can refer to the studies of Brauers and Zavadskas [58].

Eventually, the flow diagram of the MULTIMOORA method combined with H-SWARA technique for selecting the optimal renewable energy source is illustrated in Figure 2. Furthermore, in order to develop a better understanding of the current methodology a real-world case study in regards to a renewable energy source technology selection process is presented in Section 4.

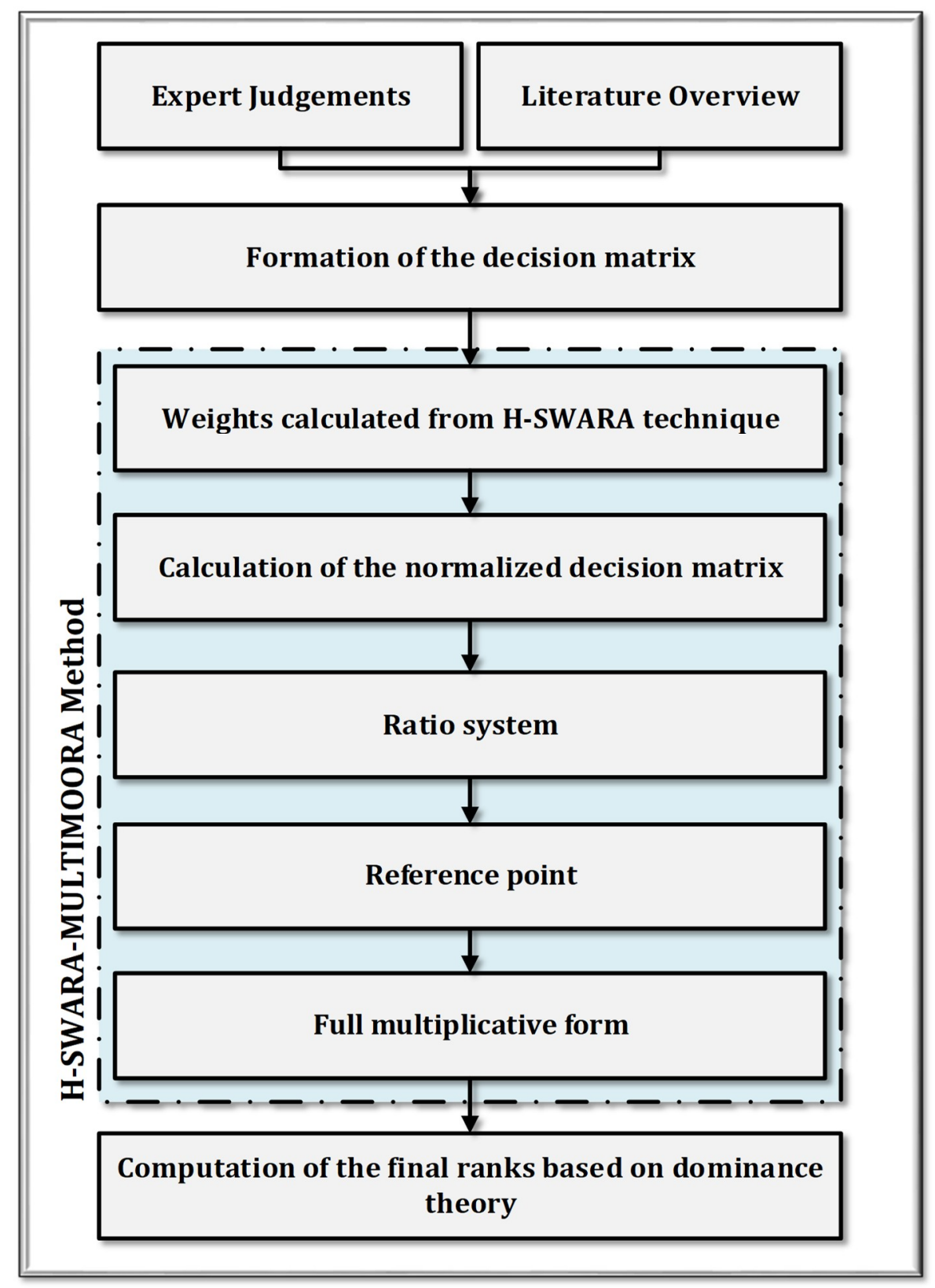

Figure 2. Flow diagram of selecting the optimal renewable energy source technology utilizing the H-SWARA-MULTIMOORA approach. 


\section{Findings and Results}

The current study is a practical implementation of the H-SWARA-MULTIMOORA approach in order to clarify a conceptual development program in regards to a renewable energy technology selection problem. One of the main purposes of the current study, after identifying the accurate selection criteria and alternatives for the proposed problem, is to present a hybrid technique based on the combination of the hierarchical SWARA method with the MULTIMOORA method. Moreover, the data collection procedure of the current study is based on a conceptual development program in Iran. The case study of this conceptual development program was analyzed in order to choose an optimal renewable energy technology in a large desert lying in the middle of the Iranian plateau called the Dasht e Kavir or Great Salt Desert.

The primary climate structure in Dasht e Kavir is dry, which receives little rainfall or snow. The mountains that surround Dasht e Kavir deliver adequate amount of runoff which is enough to create massive seasonal lakes, marshlands and playas. In regard to the temperature it can reach $50{ }^{\circ} \mathrm{C}$ $\left(122^{\circ} \mathrm{F}\right)$ in summer, and the average temperature in December to January is $22^{\circ} \mathrm{C}\left(72{ }^{\circ} \mathrm{F}\right)$. Temperatures of day and night can fluctuate as much as $70^{\circ} \mathrm{C}\left(158^{\circ} \mathrm{F}\right)$ over various times of the year. It is also worth mentioning that rainfall usually occurs in winter. There are also occasional sandstorms happening between January and March along with marshes, seasonal lakes and seasonal river beds.

The proposed project is maintained by a multi-cultural cross-industrial organization targeting green developments in Iran. The reason that this area has been selected for future renewable energy development is a sustainability program that the government suggested in order to increase the green developments of the Dasht e Kavir area.

The mentioned sustainability program was established based on a core research program, in which both sensible and rational technologies along with drastic measures and developments have been considered in order to modify an extensive overview of all the available technologies.

Furthermore, the renewable energy technologies by means of alternatives are based on the conceptual development case-study selected by experts, including; (A1) Wind energy (Wind turbine), (A2) Photovoltaic system, (A3) Solar thermal energy (STE), (A4) Geothermal energy/power, (A5) Hydropower energy, (A6) Biogas and Biofuel. Nevertheless, alternatives and the selection criteria of the current study were selected based on expert comments along with the influence of previous literature, but mostly these considerations are based on the case-study that was provided from the green development program in Iran.

It is clear that, from the short description that was mentioned about the Dasht e Kavir area, some of the considered alternatives may count as far-reaching and drastic measures. This attention is only because of the nature of a conceptual development program, which is conceptual to the core. Figure 3 illustrates the selected area in regard to establishing a renewable energy technology based on a conceptual development program in the Dasht e Kavir area.

A set of criteria for applying the proposed hybrid approach were collected and identified based on previous literature on renewable energies and sustainable evaluation, along with the considerations of the real-world conceptual development program case-study that is proposed in the current study, which have been categorized in Table 1 including the description of each criterion and their related sub-criteria.

Additionally, the population of the current study includes specialists, policymakers, and academics who took part in the location selection problem of the case-study, who are also responsible and directly dealing with the final decision of the renewable energy selection problem. Furthermore, the essential research data used in the current case-study has been collected through interview, based on a question and answer (Q\&A) approach. The linguistic terms of the Q\&A along with the numerical values of has been demonstrated in Table 2. 
Table 1. Selection criteria and sub-criteria for renewable energy technology assessment (References [1,2,10,11,13,60,61]).

\begin{tabular}{|c|c|c|c|c|}
\hline $\begin{array}{l}\text { Criteria } \\
\text { ID }\end{array}$ & Criteria & Sub-Criteria ID & $\begin{array}{l}\text { Sub-Criteria } \\
\text { (Functional } \\
\text { Requirement) }\end{array}$ & Description/Definition \\
\hline \multirow{3}{*}{$\mathrm{C} 1$} & \multirow{3}{*}{$\begin{array}{l}\text { Economic } \\
\text { Aspects }\end{array}$} & SC1 & $\begin{array}{l}\text { Investment cost } \\
\text { (Minimum) }\end{array}$ & $\begin{array}{l}\text { One of the significant attributes of selecting the optimal } \\
\text { renewable energy source is the primary investment cost } \\
\text { that has to be funded in order to start the project. }\end{array}$ \\
\hline & & SC2 & $\begin{array}{l}\text { Operation and } \\
\text { Maintenance Cost } \\
\text { (Minimum) }\end{array}$ & $\begin{array}{l}\text { It is clear that only with intensive care and maintenance } \\
\text { high-tech equipment, such as renewable energy sources, } \\
\text { will stay operational. Therefore, there might be many } \\
\text { costs imposed on the operational procedures. }\end{array}$ \\
\hline & & SC3 & $\begin{array}{l}\text { Income Generation } \\
\text { Potential } \\
\text { (Maximum) }\end{array}$ & $\begin{array}{l}\text { Although the main purpose of the renewable energies is } \\
\text { to replace limited sources of energy such as fossil fuels } \\
\text { in regard to their limitations, it is still important for } \\
\text { policymakers to comprehend renewables as sources for } \\
\text { additional revenue. }\end{array}$ \\
\hline \multirow{5}{*}{$\mathrm{C} 2$} & \multirow{5}{*}{$\begin{array}{l}\text { Technical } \\
\text { Aspects }\end{array}$} & $\mathrm{SC} 4$ & $\begin{array}{l}\text { Energy Efficiency } \\
\text { (Maximum) }\end{array}$ & $\begin{array}{l}\text { One of the essential elements in selecting the optimal } \\
\text { renewable energy is the conversion and efficiency rate of } \\
\text { the specified technologies in order to select the most } \\
\text { appropriate and ideal technology. }\end{array}$ \\
\hline & & SC5 & $\begin{array}{l}\text { Energy Production } \\
\text { Amount } \\
\text { (Maximum) }\end{array}$ & $\begin{array}{l}\text { One of the important characteristics of optimal } \\
\text { renewable energy technology is the amount of energy } \\
\text { production. Obviously, the higher the amount a } \\
\text { technology produces, it is superior to other technologies. }\end{array}$ \\
\hline & & SC6 & $\begin{array}{l}\text { The Degree of } \\
\text { Sophistication } \\
\text { (Minimum) }\end{array}$ & $\begin{array}{l}\text { One of the critical factors in selecting any kind of } \\
\text { technology is the level of sophistication because it is } \\
\text { important to make sure that the efficiency of energy } \\
\text { production will not decrease due to complication and } \\
\text { lack of appropriate knowledge. }\end{array}$ \\
\hline & & SC7 & $\begin{array}{l}\text { Reliability } \\
\text { (Maximum) }\end{array}$ & $\begin{array}{l}\text { Compatibility with the environmental properties along } \\
\text { with the reliability over a long period with the } \\
\text { environmental settings of the establishment are } \\
\text { important attributes for selecting the optimal technology. }\end{array}$ \\
\hline & & SC8 & $\begin{array}{l}\text { Emission and } \\
\text { Pollution } \\
\text { (Minimum) }\end{array}$ & $\begin{array}{l}\text { While one of the primary purposes of replacing limited } \\
\text { sources of energy with renewable energies is the } \\
\text { environmental aspects and reduction of pollution } \\
\text { factors, utilizing such technologies might also have } \\
\text { minor environmental damages which should be } \\
\text { considered in the selection process. }\end{array}$ \\
\hline \multirow{3}{*}{$\mathrm{C} 3$} & \multirow{3}{*}{$\begin{array}{c}\text { Social } \\
\text { Concerns }\end{array}$} & SC9 & $\begin{array}{l}\text { Job Creation } \\
\text { (Maximum) }\end{array}$ & $\begin{array}{l}\text { One of the considerable aspects of any new technology } \\
\text { in the perspective of social concern is job creation. } \\
\text { Therefore, it is important to select a technology which } \\
\text { could provide such social context that could support } \\
\text { societies to improve the perspective of the cultural } \\
\text { concerns towards such technological advancements. }\end{array}$ \\
\hline & & SC10 & $\begin{array}{l}\text { Long-Term Risk } \\
\text { Levels (Minimum) }\end{array}$ & $\begin{array}{l}\text { The cost of devaluation and depreciation over a long } \\
\text { period might be the reason that policymakers negate to } \\
\text { agree to establish specific technologies. As such } \\
\text { technologies and the related knowledge is novel to } \\
\text { many countries, they consider the long-term risk factors } \\
\text { with higher attention in order to choose a technology } \\
\text { which contains the minimum amount of risk levels in } \\
\text { regard to socio-economic aspects. }\end{array}$ \\
\hline & & SC11 & $\begin{array}{l}\text { International and } \\
\text { Domestic Support } \\
\text { (Maximum) }\end{array}$ & $\begin{array}{l}\text { It is a clear fact that without the support of international } \\
\text { and governmental policy-makers, it is close to } \\
\text { impossible to facilitate and establish a renewable energy } \\
\text { in a practical way. As these projects still count as vanity } \\
\text { projects in many third world countries, it is problematic } \\
\text { and difficult to gain the attention of government policy } \\
\text { makers in regard to renewable technologies. }\end{array}$ \\
\hline
\end{tabular}




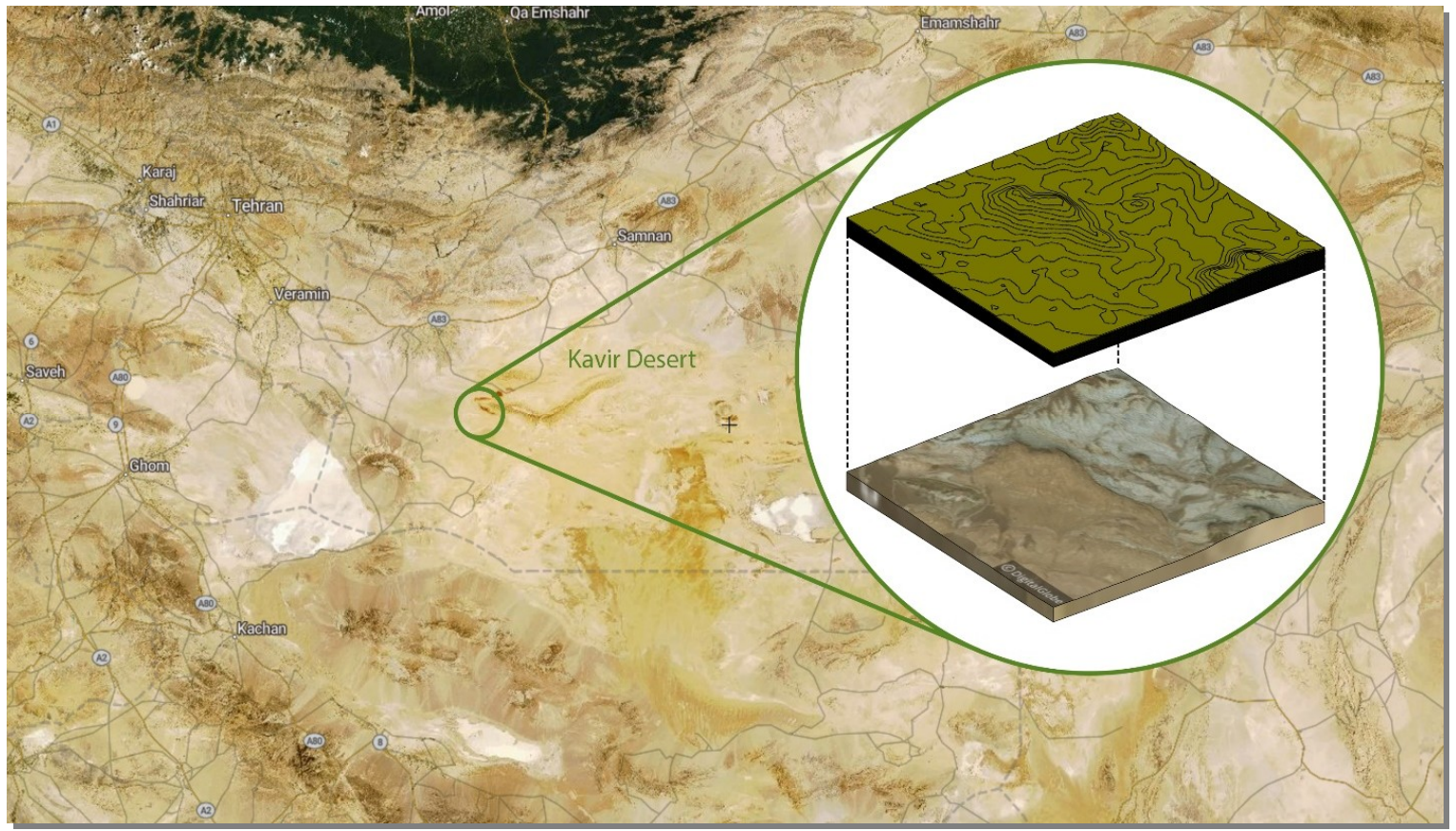

Figure 3. The geographical area of the sustainable/green development project.

Table 2. Linguistic indicator and the corresponding numbers.

\begin{tabular}{ccc}
\hline Linguistic Indicator & Alphabetic Values of Verbal Comments & Numerical Value of Verbal Comments \\
\hline Very Poor & VP & 1 \\
Poor & P & 2 \\
Moderate & M & 3 \\
Good & G & 4 \\
Very Good & VG & 5 \\
\hline
\end{tabular}

The definitive target of the Q\&A was to complete the decision matrix shown in Table 3 based on the linguistic definitions and the corresponding numbers.

It is important to mention that the suggested case-study in this research was not chosen randomly. This particular case was targeted in order to analyze a specific area in Iran, in regard to selecting an optimal renewable energy source based on several criteria obtaining detailed understandings that other case studies would not be able to offer due to the specific structure of the conceptual development program in the area of Dasht e Kavir, which is also changeable in case of modification in the environment and projects.

Table 3. Decision matrix for selecting the optimal renewable energy technology.

\begin{tabular}{|c|c|c|c|c|c|c|c|c|c|c|c|}
\hline \multirow{3}{*}{ Renewable Energy Technology } & \multicolumn{11}{|c|}{ Criteria and Sub-Criteria } \\
\hline & \multicolumn{3}{|c|}{$\mathrm{C1}$} & \multicolumn{5}{|c|}{$\mathrm{C} 2$} & \multicolumn{3}{|c|}{$\mathrm{C} 3$} \\
\hline & SC1 & SC2 & SC3 & SC4 & SC5 & SC6 & SC7 & SC8 & SC9 & SC10 & SC11 \\
\hline Wind energy (Wind turbine) [A1] & 3 & 3 & 3 & 3 & 3 & 2 & 3 & 1 & 4 & 3 & 3 \\
\hline Photovoltaic system [A2] & 2 & 2 & 3 & 3 & 4 & 2 & 4 & 1 & 2 & 2 & 3 \\
\hline Solar thermal energy (STE) [A3] & 3 & 2 & 3 & 3 & 3 & 3 & 3 & 1 & 2 & 2 & 3 \\
\hline Geothermal energy/power [A4] & 3 & 3 & 2 & 3 & 3 & 3 & 3 & 2 & 2 & 3 & 2 \\
\hline Hydropower energy [A5] & 4 & 4 & 4 & 4 & 4 & 3 & 2 & 2 & 3 & 4 & 1 \\
\hline Biogas and Biofuel [A6] & 3 & 3 & 3 & 2 & 3 & 3 & 3 & 2 & 3 & 2 & 2 \\
\hline
\end{tabular}

As comprehensively mentioned in Section 3, in the current study, after identification of criteria and alternatives which forms the main decision matrix, the first step is to calculate the optimal weights 
of criteria and sub-criteria based on the H-SWARA technique. In order to calculate the weight of criteria and sub-criteria of the renewable energy selection problem, this study used a hierarchical form based on the calculation procedure of the AHP methodology.

In this regard, weights of sub-criteria related to each criterion should be calculated, after calculating criteria and sub-criteria weights, the final weight of each sub-criteria will be obtained based on a simple multiplication of sub-criteria to the associated criteria. As mentioned in the previous sections, the first step of using the H-SWARA method is to obtain the order of criteria based on preferences of decision-makers in order to calculate the final weights of the SWARA approach.

Accordingly, Table 4 demonstrates the final results of the criteria and sub-criteria weights utilizing the H-SWARA method including managerial aspects and technical specification.

Table 4. Final results of the H-SWARA method to weight the selection criteria.

\begin{tabular}{|c|c|c|c|c|c|c|}
\hline Sub-Criterion & $\begin{array}{l}\text { Order Based on } \\
\text { Significance }\end{array}$ & $\begin{array}{l}\text { The Comparative } \\
\text { Importance of } \\
\text { Average Value } s_{j}\end{array}$ & $\begin{array}{c}\text { Coefficient } \\
k_{j}\end{array}$ & $\begin{array}{l}\text { Recalculated } \\
\text { Weight } w_{j}\end{array}$ & $\begin{array}{c}\text { Final } \\
\text { Weight } q_{j}\end{array}$ & $\begin{array}{l}\text { H-SWARA } \\
\text { Weights }\end{array}$ \\
\hline SC1 & 1 & - & 1 & 1 & 0.468 & 0.240 \\
\hline SC2 & 2 & 4 & 1.444 & 0.692 & 0.324 & 0.166 \\
\hline SC3 & 3 & 5 & 1.556 & 0.445 & 0.208 & 0.107 \\
\hline SC4 & 3 & 4 & 1.444 & 0.519 & 0.171 & 0.034 \\
\hline SC5 & 1 & 1 & - & 1 & 0.329 & 0.066 \\
\hline SC6 & 5 & 2 & 1.222 & 0.348 & 0.114 & 0.023 \\
\hline SC7 & 2 & 3 & 1.333 & 0.750 & 0.247 & 0.049 \\
\hline SC8 & 4 & 2 & 1.222 & 0.425 & 0.140 & 0.028 \\
\hline SC9 & 2 & 4 & 1.444 & 0.692 & 0.328 & 0.095 \\
\hline SC10 & 3 & 6 & 1.667 & 0.415 & 0.197 & 0.057 \\
\hline SC11 & 1 & 1 & - & 1 & 0.474 & 0.137 \\
\hline Criterion & $\begin{array}{l}\text { Order Based on } \\
\text { Significance }\end{array}$ & $\begin{array}{l}\text { The Comparative } \\
\text { Importance of } \\
\text { Average Value } s_{j}\end{array}$ & $\begin{array}{c}\text { Coefficient } \\
k_{j}\end{array}$ & $\begin{array}{l}\text { Recalculated } \\
\text { Weight } w_{j}\end{array}$ & $\begin{array}{c}\text { Final } \\
\text { Weight } q_{j}\end{array}$ & \\
\hline $\mathrm{C} 1$ & 1 & - & 1 & 1 & 0.512 & \\
\hline $\mathrm{C} 2$ & 3 & 4 & 1.444 & 0.389 & 0.288 & \\
\hline $\mathrm{C} 3$ & 2 & 7 & 1.778 & 0.563 & 0.200 & \\
\hline
\end{tabular}

It is just a clear fact that, based on the result of the H-SWARA method investment cost, operation and maintenance cost, and international and domestic support counts as the most important factors in the process of the proposed technology selection problem, respectively. Clearly, due to the novelty and complexity of such technologies, a substantial financial plan regarding investment along with operational and maintenance cost is needed [62]. Moreover, because these sustainability development projects are considered mega projects without major sponsorships of international and domestic organizations along with governmental support, it is near to impossible to promote and assemble such projects.

Consequently, based on the calculated weights of the criteria and the preliminary decision matrix formed based on expert comments and previous literature, the final decision matrix of the current study is presented in Table 5, which includes the comments along with weights of criteria calculated from the H-SWARA method.

Moreover, as aforementioned in previous sections, in order to utilize the MULTIMOORA method, the decision matrix has to transform into dimensionless numbers based on a normalization technique in order to form a dimensionless decision matrix. Therefore, in the current study in order to compare normalized numbers to each other and form a normalized matrix, Equation (6) was used. The normalized decision matrix is shown in Table 6. 
Table 5. Decision matrix for selecting the optimal renewable energy technology with final criteria weights.

\begin{tabular}{|c|c|c|c|c|c|c|c|c|c|c|c|}
\hline \multirow{3}{*}{$\begin{array}{c}\text { Renewable Energy } \\
\text { Technology }\end{array}$} & \multicolumn{11}{|c|}{ Criteria and Sub-Criteria } \\
\hline & \multicolumn{3}{|c|}{$\mathrm{C} 1$} & \multicolumn{5}{|c|}{$\mathrm{C} 2$} & \multicolumn{3}{|c|}{$\mathrm{C3}$} \\
\hline & SC1 & $\mathrm{SC2}$ & SC3 & SC4 & SC5 & SC6 & SC7 & SC8 & SC9 & SC10 & SC11 \\
\hline A1 & 3 & 3 & 3 & 3 & 3 & 2 & 3 & 1 & 4 & 3 & 3 \\
\hline A2 & 2 & 2 & 3 & 3 & 4 & 2 & 4 & 1 & 2 & 2 & 3 \\
\hline A3 & 3 & 2 & 3 & 3 & 3 & 3 & 3 & 1 & 2 & 2 & 3 \\
\hline $\mathrm{A} 4$ & 3 & 3 & 2 & 3 & 3 & 3 & 3 & 2 & 2 & 3 & 2 \\
\hline A5 & 4 & 4 & 4 & 4 & 4 & 3 & 2 & 2 & 3 & 4 & 1 \\
\hline A6 & 3 & 3 & 3 & 2 & 3 & 3 & 3 & 2 & 3 & 2 & 2 \\
\hline H-SWARA weights & 0.240 & 0.166 & 0.107 & 0.034 & 0.066 & 0.023 & 0.049 & 0.028 & 0.095 & 0.057 & 0.137 \\
\hline
\end{tabular}

Table 6. Normalized decision matrix for selecting the optimal renewable energy technology.

\begin{tabular}{|c|c|c|c|c|c|c|c|c|c|c|c|}
\hline \multirow{3}{*}{$\begin{array}{c}\text { Renewable Energy } \\
\text { Technology }\end{array}$} & \multicolumn{11}{|c|}{ Criteria and Sub-Criteria } \\
\hline & \multicolumn{3}{|c|}{$\mathrm{C} 1$} & \multicolumn{5}{|c|}{$\mathrm{C} 2$} & \multicolumn{3}{|c|}{$\mathrm{C} 3$} \\
\hline & SC1 & SC2 & SC3 & SC4 & SC5 & SC6 & SC7 & SC8 & SC9 & SC10 & SC11 \\
\hline A1 & 0.400 & 0.420 & 0.400 & 0.400 & 0.363 & 0.301 & 0.400 & 0.258 & 0.589 & 0.442 & 0.500 \\
\hline A2 & 0.267 & 0.280 & 0.400 & 0.400 & 0.485 & 0.301 & 0.534 & 0.258 & 0.294 & 0.294 & 0.500 \\
\hline A3 & 0.400 & 0.280 & 0.400 & 0.400 & 0.363 & 0.452 & 0.400 & 0.258 & 0.294 & 0.294 & 0.500 \\
\hline A4 & 0.400 & 0.420 & 0.267 & 0.400 & 0.363 & 0.452 & 0.400 & 0.516 & 0.294 & 0.442 & 0.333 \\
\hline A5 & 0.534 & 0.560 & 0.534 & 0.534 & 0.485 & 0.452 & 0.267 & 0.516 & 0.442 & 0.589 & 0.166 \\
\hline A6 & 0.400 & 0.420 & 0.400 & 0.267 & 0.363 & 0.452 & 0.400 & 0.516 & 0.442 & 0.294 & 0.332 \\
\hline H-SWARA weights & 0.240 & 0.166 & 0.107 & 0.034 & 0.066 & 0.023 & 0.049 & 0.028 & 0.095 & 0.057 & 0.137 \\
\hline
\end{tabular}

Accordingly, based on the weights calculated from the H-SWARA approach along with the normalized decision matrix, the assessment values and final ranks of the integrated H-SWARA-MULTIMOORA method can be calculated based on Equations (7), (10) and (13) for the ratio system $y_{i}^{*}$, the reference point approach $z_{i}^{*}$, and the full multiplicative form $u_{i}^{*}$, respectively. Table 7 determines the final results of the proposed approach in the suggested renewable energy technology selection. Furthermore, the ranking of the H-SWARA-MULTIMOORA approach is acquired by the assessment values and the final rank of the method regarding dominance theory.

Table 7. Assessment values and rankings of the H-SWARA-MULTIMOORA approach for the renewable energy technology selection problem.

\begin{tabular}{cccccccc}
\hline \multirow{2}{*}{$\begin{array}{c}\text { Renewable Energy } \\
\text { Technology }\end{array}$} & \multicolumn{3}{c}{ Assessment Values } & \multicolumn{3}{c}{ Ranks } & \multirow{2}{*}{ Final Rank } \\
\cline { 2 - 6 } & $\boldsymbol{y}_{\boldsymbol{i}}^{*}$ & $\boldsymbol{z}_{\boldsymbol{i}}^{*}$ & $\boldsymbol{u}_{\boldsymbol{i}}^{*}$ & $\boldsymbol{y}_{\boldsymbol{i}}^{*}$ & $\boldsymbol{z}_{\boldsymbol{i}}^{*}$ & $\boldsymbol{u}_{\boldsymbol{i}}^{*}$ & \\
\hline A1 & 0.019 & 0.032 & 1.093 & 3 & 3 & 3 & 3 \\
A2 & 0.69 & 0.028 & 1.277 & 1 & 1 & 1 & 1 \\
A3 & 0.019 & 0.032 & 1.110 & 2 & 2 & 2 & 2 \\
A4 & -0.056 & 0.032 & 0.901 & 5 & 4 & 5 & 5 \\
A5 & -0.094 & 0.064 & 0.810 & 6 & 6 & 6 & 6 \\
A6 & -0.024 & 0.032 & 0.987 & 4 & 5 & 4 & 4 \\
\hline
\end{tabular}

Consequently, it is clear that based on the H-SAWARA-MULTIMOORA approach, the best renewable energy solution for the area of Dasht e Kavir is the Photovoltaic system. While Iran is one of the richest countries in regard to multiple energy sources with an extensive amount of fossil fuels, such as petroleum and natural gas, it is unfortunate that with a high potential of renewable energy establishments, there is only a little attention to renewable energies. The results of the current study showed that the suggested area of Dasht e Kavir is a possible establishment target to find renewable energy sources such as Photovoltaic systems. In addition, it is worth mentioning that the solar thermal energy and wind energy obtained second and third place, respectively, because of the specified geographical properties of the Dasht e Kavir. 
One of the main reasons that wind energy is also considered in this area is due to the light and heavy sand storms during different seasons. Ultimately, although based on the findings of the current study and expert comments the Photovoltaic system is the most appropriate renewable energy technology for the area of Dasht e Kavir, it is worth mentioning that a hybrid approach in such areas is also recommended in this study. In other words, due to a vast amount of winds along with the astral nature of the desert, and because in this study it has been shown that the Photovoltaic system, solar thermal energy and wind energy are the best solutions, one of the solutions in the development program could be a combination establishment of these technologies in order to obtain the optimal energy output.

\section{Conclusions}

It is clear that the rapid progression of energy appeals due to the increase in population and production companies, along with the escalation of air pollutants and greenhouse gas emissions, causing substantial developments on renewable energies and their associated technologies. Outstanding expansions and developments of interdisciplinary research studies produced various alternatives in the case of renewable energies based on multiple considerations, such as socio-economic and environmental issues. This only means renewable energy technology selection problems are a similar complex problem based on multiple criteria and alternatives, due to the complication of evaluating different technologies and renewable energy sources with multiple attributes.

The current study proposed a hybrid MADM evaluation for selecting the optimal renewable energy technology in a conceptual development project in Iran. After a comprehensive identification of the assessment criteria based on previous literature, candidate technology alternatives for the renewable energy sources were provided based on expert judgments, in order to establish a primary decision matrix. Moreover, the MULTIMOORA approach integrated with the hierarchical SWARA technique was utilized to provide an assessment of the optimal renewable energy technologies applied to a conceptual case-study, in a multi-cultural cross-industrial organization targeting green developments in Iran. Consequently, based on the final assessment of the decision-making problem, it was shown that the best renewable energy solutions for the area of Dasht e Kavir are the Photovoltaic system, thermal energy and wind energy, respectively. The findings of the current study conclude that although Iran is one of the richest countries in regard to specific sources, such as petroleum and natural gas, there is a huge potential in order to enrich and revise the possible policies on sustainable development programs and renewable energy sources.

Suggestions for forthcoming developments of the proposed study may be as the following. First, the input data of the MADM approach can be integrated with certain mathematical structures such as fuzzy sets in order to comprehend uncertainty in the methodology. Second, it is suggested to implement such methodology in other geographical locations within the analyzed country and outside that area, and to compare the results of such analyses with the outcomes of the current study. Third, although the current study selected a specific renewable energy technology, it is clear that different criteria will have different effects on the decision process. Therefore, it is strongly recommended to analyze the same problem in the same geographical location based on different criteria and assessment models, and to compare the result to this study in order to obtain a comparison of different views and perspectives for the proposed, similar complex problem.

Author Contributions: Conceptualization, A.I.M. (Abteen Ijadi Maghsoodi) and A.I.M. (Arta Ijadi Maghsoodi); methodology, A.I.M. (Abteen Ijadi Maghsoodi); validation, A.M., E.K.Z. and T.R.; investigation, A.I.M. (Abteen Ijadi Maghsoodi); resources, A.I.M. (Arta Ijadi Maghsoodi); data curation, A.I.M. (Abteen Ijadi Maghsoodi); writing-original draft preparation, A.I.M. (Abteen Ijadi Maghsoodi), A.I.M. (Arta Ijadi Maghsoodi) and A.M.; writing-review and editing, A.I.M. (Abteen Ijadi Maghsoodi), A.M., E.K.Z., T.R.; supervision, E.K.Z., T.R., A.M.; project administration, A.I.M. (Abteen Ijadi Maghsoodi).

Funding: This research received no external funding. 
Acknowledgments: The authors would like to thank the anonymous reviewers for their insightful comments and constructive suggestions. Additionally, the authors wish to appreciatively acknowledge Arsalan Rokhnejad who helped us with the data resources in our research study.

Conflicts of Interest: The authors declare no conflict of interest.

\section{References}

1. Yazdani-Chamzini, A.; Fouladgar, M.M.; Zavadskas, E.K.; Moini, S.H.H. Selecting the optimal renewable energy using multi criteria decision making. J. Bus. Econ. Manag. 2013, 14, 957-978. [CrossRef]

2. Yazdani, M.; Chatterjee, P.; Zavadskas, E.K.; Streimikiene, D. A novel integrated decision-making approach for the evaluation and selection of renewable energy technologies. Clean Technol. Environ. Policy 2018, 20, 403-420. [CrossRef]

3. Mardani, A.; Zavadskas, E.K.; Streimikiene, D.; Jusoh, A.; Nor, K.M.D.; Khoshnoudi, M. Using fuzzy multiple criteria decision making approaches for evaluating energy saving technologies and solutions in five star hotels: A new hierarchical framework. Energy 2016, 117, 131-148. [CrossRef]

4. Çolak, M.; Kaya, İ. Prioritization of renewable energy alternatives by using an integrated fuzzy MCDM model: A real case application for Turkey. Renew. Sustain. Energy Rev. 2017, 80, 840-853. [CrossRef]

5. Büyüközkan, G.; Karabulut, Y.; Mukul, E. A novel renewable energy selection model for United Nations' sustainable development goals. Energy 2018, 165, 290-302. [CrossRef]

6. Kaya, T.; Kahraman, C. Multicriteria renewable energy planning using an integrated fuzzy VIKOR \& AHP methodology: The case of Istanbul. Energy 2010, 35, 2517-2527.

7. Ahmad, S.; Tahar, R.M. Selection of renewable energy sources for sustainable development of electricity generation system using analytic hierarchy process: A case of Malaysia. Renew. Energy 2014, 63, 458-466. [CrossRef]

8. Şengül, Ü.; Eren, M.; Shiraz, S.E.; Gezder, V.; Şengül, A.B.; Shiraz, S.E.; Gezder, V. Fuzzy TOPSIS method for ranking renewable energy supply systems in Turkey. Renew. Energy 2015, 75, 617-625. [CrossRef]

9. Ignatius, J.; Rahman, A.; Yazdani, M.; Šaparauskas, J.; Haron, S.H. An integrated fuzzy ANP-QFD approach for green building assessment. J. Civ. Eng. Manag. 2016, 22, 551-563. [CrossRef]

10. Büyüközkan, G.; Güleryüz, S. An integrated DEMATEL-ANP approach for renewable energy resources selection in Turkey. Int. J. Prod. Econ. 2016, 182, 435-448. [CrossRef]

11. Kumar, A.; Sah, B.; Singh, A.R.; Deng, Y.; He, X.; Kumar, P.; Bansal, R.C. A review of multi criteria decision making (MCDM) towards sustainable renewable energy development. Renew. Sustain. Energy Rev. 2017, 69, 596-609. [CrossRef]

12. Haddad, B.; Liazid, A.; Ferreira, P. A multi-criteria approach to rank renewables for the Algerian electricity system. Renew. Energy 2017, 107, 462-472. [CrossRef]

13. Büyüközkan, G.; Güleryüz, S. Evaluation of Renewable Energy Resources in Turkey using an integrated MCDM approach with linguistic interval fuzzy preference relations. Energy 2017, 123, 149-163. [CrossRef]

14. Van de Kaa, G.; Kamp, L.; Rezaei, J. Selection of biomass thermochemical conversion technology in the Netherlands: A best worst method approach. J. Clean. Prod. 2017, 166, 32-39. [CrossRef]

15. Wu, Y.; Xu, C.; Zhang, T. Evaluation of renewable power sources using a fuzzy MCDM based on cumulative prospect theory: A case in China. Energy 2018, 147, 1227-1239. [CrossRef]

16. Karunathilake, H.; Hewage, K.; Mérida, W.; Sadiq, R. Renewable energy selection for net-zero energy communities: Life cycle based decision making under uncertainty. Renew. Energy 2019, 130, 558-573. [CrossRef]

17. Brauers, W.K.M.; Zavadskas, E.K. The MOORA method and its application to privatization in a transition economy by A new method: The MOORA method. Control Cybern. 2006, 35, 445-469.

18. Akkaya, G.; Turanoğlu, B.; Öztaş, S. An integrated fuzzy AHP and fuzzy MOORA approach to the problem of industrial engineering sector choosing. Expert Syst. Appl. 2015, 42, 9565-9573. [CrossRef]

19. Çebi, F.; Otay, İ. A two-stage fuzzy approach for supplier evaluation and order allocation problem with quantity discounts and lead time. Inf. Sci. (Ny) 2016, 339, 143-157. [CrossRef]

20. Mishra, S.; Sahu, A.K.; Datta, S.; Mahapatra, S.S. Application of fuzzy integrated MULTIMOORA method towards supplier/partner selection in agile supply chain. Int. J. Oper. Res. 2015, 22, 466-514. [CrossRef] 
21. Hafezalkotob, A.; Hafezalkotob, A. Interval target-based VIKOR method supported on interval distance and preference degree for machine selection. Eng. Appl. Artif. Intell. 2017, 57, 184-196. [CrossRef]

22. Altuntas, S.; Dereli, T.; Yilmaz, M.K. Evaluation of excavator technologies: Application of data fusion based MULTIMOORA methods. J. Civ. Eng. Manag. 2015, 21, 977-997. [CrossRef]

23. Liu, H.C.; Fan, X.J.; Li, P.; Chen, Y.Z. Evaluating the risk of failure modes with extended MULTIMOORA method under fuzzy environment. Eng. Appl. Artif. Intell. 2014, 34, 168-177. [CrossRef]

24. Hafezalkotob, A.; Hafezalkotob, A.; Sayadi, M.K. Extension of MULTIMOORA method with interval numbers: An application in materials selection. Appl. Math. Model. 2016, 40, 1372-1386. [CrossRef]

25. Deliktas, D.; Ustun, O. Student selection and assignment methodology based on fuzzy MULTIMOORA and multichoice goal programming. Int. Trans. Oper. Res. 2017, 24, 1173-1195. [CrossRef]

26. Maghsoodi, A.I.; Abouhamzeh, G.; Khalilzadeh, M.; Zavadskas, E.K. Ranking and selecting the best performance appraisal method using the MULTIMOORA approach integrated Shannon's entropy. Front. Bus. Res. China 2018, 12, 2. [CrossRef]

27. Brauers, W.K.M.; Zavadskas, E.K.; Lepkova, N. The future of facilities management in Lithuania. Rom. J. Econ. Forecast. 2017, 20, 98-115.

28. Wu, X.; Liao, H.; Xu, Z.; Hafezalkotob, A.; Herrera, F. Probabilistic Linguistic MULTIMOORA: A Multi-Criteria Decision Making Method Based on the Probabilistic Linguistic Expectation Function and the Improved Borda Rule. IEEE Trans. Fuzzy Syst. 2018, 6706, 1. [CrossRef]

29. Maghsoodi, A.I.; Kavian, A.; Khalilzadeh, M.; Brauers, W.K.M. CLUS-MCDA: A Novel Framework based on Cluster Analysis and Multiple Criteria Decision Theory in a Supplier Selection Problem. Comput. Ind. Eng. 2018, 118, 409-422. [CrossRef]

30. Peng, H.; Wang, J. A Multicriteria Group Decision-Making Method Based on the Normal Cloud Model with Zadeh's Z-numbers. IEEE Trans. Fuzzy Syst. 2018. [CrossRef]

31. Hafezalkotob, A.; Hami-Dindar, A.; Rabie, N.; Hafezalkotob, A. A decision support system for agricultural machines and equipment selection: A case study on olive harvester machines. Comput. Electron. Agric. 2018, 148, 207-216. [CrossRef]

32. Tian, Z.-P.; Wang, J.; Wang, J.-Q.; Zhang, H.-Y. An improved MULTIMOORA approach for multi-criteria decision-making based on interdependent inputs of simplified neutrosophic linguistic information. Neural Comput. Appl. 2017, 28, 585-597. [CrossRef]

33. Eghbali-Zarch, M.; Tavakkoli-Moghaddam, R.; Esfahanian, F.; Sepehri, M.M.; Azaron, A. Pharmacological therapy selection of type 2 diabetes based on the SWARA and modified MULTIMOORA methods under a fuzzy environment. Artif. Intell. Med. 2018, 87, 20-33. [CrossRef] [PubMed]

34. Keršuliene, V.; Zavadskas, E.K.; Turskis, Z. Selection of Rational Dispute Resolution Method by Applying New Step-Wise Weight Assessment Ratio Analysis (Swara). J. Bus. Econ. Manag. 2010, 11, 243-258. [CrossRef]

35. Hashemkhani Zolfani, S.; Aghdaie, M.H.; Derakhti, A.; Zavadskas, E.K.; Varzandeh, M.H.M. Decision making on business issues with foresight perspective; An application of new hybrid MCDM model in shopping mall locating. Expert Syst. Appl. 2013, 40, 7111-7121. [CrossRef]

36. Keršulienè, V.; Turskis, Z. Integrated fuzzy multiple criteria decision making model for architect selection. Technol. Econ. Dev. Econ. 2011, 17, 645-666. [CrossRef]

37. Zolfani, S.H.; Esfahani, M.H.; Bitarafan, M.; Zavadskas, E.K.; Arefi, S.L. Developing a new hybrid MCDM method for selection of the optimal alternative of mechanical longitudinal ventilation of tunnel pollutants during automobile accidents. Transport 2013, 28, 89-96. [CrossRef]

38. Zolfani, S.H.; Farrokhzad, M.; Turskis, Z. Investigating on successful factors of online games based on explorer. E+M Ekon. Manag. 2013, 16, 161-169.

39. Zolfani, S.H.; Zavadskas, E.K.; Turskis, Z. Design of Products with Both International and Local Perspectives based on Yin-Yang Balance Theory and Swara Method. Econ. Res. Istraživanja 2013, 26, 153-166. [CrossRef]

40. Zolfani, S.H.; Bahrami, M. Investment prioritizing in high tech industries based on SWARA-COPRAS approach. Technol. Econ. Dev. Econ. 2014, 20, 534-553. [CrossRef]

41. Vafaeipour, M.; Zolfani, S.H.; Varzandeh, M.H.M.; Derakhti, A.; Eshkalag, M.K. Assessment of regions priority for implementation of solar projects in Iran: New application of a hybrid multi-criteria decision making approach. Energy Convers. Manag. 2014, 86, 653-663. [CrossRef]

42. Karabasevic, D.; Paunkovic, J.; Stanujkic, D. Ranking of companies according to the indicators of corporate social responsibility based on SWARA and ARAS methods. Serbian J. Manag. 2015, 11, 43-53. [CrossRef] 
43. Zolfani, S.H.; Pourhossein, M.; Yazdani, M.; Zavadskas, E.K. Evaluating construction projects of hotels based on environmental sustainability with MCDM framework. Alexandria Eng. J. 2015, 57, 357-365. [CrossRef]

44. Zolfani, S.H.; Salimi, J.; Maknoon, R.; Kildiene, S. Technology foresight about R\&D projects selection; application of SWARA method at the policy making level. Eng. Econ. 2015, 26, 571-580.

45. Yazdani, M.; Zolfani, S.H.; Zavadskas, E.K. New integration of MCDM methods and QFD in the selection of green suppliers. J. Bus. Econ. Manag. 2016, 1699, 1-17. [CrossRef]

46. Nakhaei, J.; Bitarafan, M.; Arefi, S.L.; Kapliński, O. Model for rapid assessment of vulnerability of office buildings to blast using SWARA and SMART methods (a case study of swiss re tower). J. Civ. Eng. Manag. 2016, 22, 831-843. [CrossRef]

47. Karabasevic, D.; Zavadskas, E.K.; Turskis, Z.; Stanujkic, D. The Framework for the Selection of Personnel Based on the SWARA and ARAS Methods Under Uncertainties. Informatica 2016, 27, 49-65. [CrossRef]

48. Nakhaei, J.; Arefi, S.L.; Bitarafan, M.; Kildienè, S. Evaluation of light supply in the public underground safe spaces by using of COPRAS-SWARA methods. Int. J. Strateg. Prop. Manag. 2016, 20, 198-206. [CrossRef]

49. Tayyar, N.; Durmuş, M. Comparison of Max100, SWARA and Pairwise Weight Elicitation Methods. Int. J. Eng. Res. Appl. 2017, 7, 67-78. [CrossRef]

50. Mavi, R.K.; Goh, M.; Zarbakhshnia, N. Sustainable third-party reverse logistic provider selection with fuzzy SWARA and fuzzy MOORA in plastic industry. Int. J. Adv. Manuf. Technol. 2017, 91, 2401-2418. [CrossRef]

51. Dahooie, J.H.; Zavadskas, E.K.; Abolhasani, M.; Vanaki, A.; Turskis, Z. A novel approach for evaluation of projects using an interval-valued fuzzy additive ratio assessment (ARAS) method: A case study of oil and gas well drilling projects. Symmetry 2018, 10, 45. [CrossRef]

52. Dahooie, J.H.; Abadi, E.B.J.; Vanaki, A.S.; Firoozfar, H.R. Competency-based IT personnel selection using a hybrid SWARA and ARAS-G methodology. Hum. Factors Ergon. Manuf. 2018, 28, 5-16. [CrossRef]

53. Saaty, T.L. How to make a decision: The analytic hierarchy process. Eur. J. Oper. Res. 1990, 48, 9-26. [CrossRef]

54. Saaty, T.L. Decision making with the analytic hierarchy process. Int. J. Serv. Sci. 2008, 1, 83. [CrossRef]

55. Brauers, W.K.M.; Zavadskas, E.K. Project management by multimoora as an instrument for transition economies. Technol. Econ. Dev. Econ. 2010, 16, 5-24. [CrossRef]

56. Brauers, W.K.M.; Baležentis, A.; Baležentis, T. Multimoora for the EU member states updated with fuzzy number theory. Technol. Econ. Dev. Econ. 2011, 17, 259-290. [CrossRef]

57. Brauers, W.K.M.; Zavadskas, E.K. Robustness of MULTIMOORA: A method for multi-objective optimization. Informatica 2012, 23, 1-25.

58. Brauers, W.K.M.; Zavadskas, E.K. Multimoora Optimization Used to Decide on a Bank Loan to Buy Property. Technol. Econ. Dev. Econ. 2011, 17, 174-188. [CrossRef]

59. Hafezalkotob, A.; Hafezalkotob, A. Comprehensive MULTIMOORA method with target-based attributes and integrated significant coefficients for materials selection in biomedical applications. Mater. Des. 2015, 87, 949-959. [CrossRef]

60. Bahrami, M.; Abbaszadeh, P. An overview of renewable energies in Iran. Renew. Sustain. Energy Rev. 2013, 24, 198-208. [CrossRef]

61. Mollahosseini, A.; Hosseini, S.A.; Jabbari, M.; Figoli, A.; Rahimpour, A. Renewable energy management and market in Iran: A holistic review on current state and future demands. Renew. Sustain. Energy Rev. 2017, 80, 774-788. [CrossRef]

62. Maghsoodi, A.I.; Hafezalkotob, A.; Ari, I.A.; Maghsoodi, S.I.; Hafezalkotob, A. Selection of Waste Lubricant Oil Regenerative Technology Using Entropy-Weighted Risk-Based Fuzzy Axiomatic Design Approach. Informatica 2018, 29, 41-74. [CrossRef]

(C) 2018 by the authors. Licensee MDPI, Basel, Switzerland. This article is an open access article distributed under the terms and conditions of the Creative Commons Attribution (CC BY) license (http:/ / creativecommons.org/licenses/by/4.0/). 